\title{
Effect of Moringa olifera Leaf Extract on Growth and Productivity of Three Cereal Forages
}

\author{
Awad O. Abusuwar ${ }^{1} \&$ Refaat A. Abohassan ${ }^{1}$ \\ ${ }^{1}$ Department of Arid Land Agriculture, College of Meteorology, Environment and Arid Land Agriculture, King \\ Abdulaziz University, Jeddah, Saudi Arabia \\ Correspondence: Awad O. Abusuwar, Department of Arid Land Agriculture, College of Meteorology, \\ Environment and Arid Land Agriculture, King Abdulaziz University, Jeddah 21589, Saudi Arabia. E-mail: \\ aabusuwar@kau.edu.sa
}

Received: April 23, 2017

Accepted: May 27, $2017 \quad$ Online Published: June 15, 2017

doi:10.5539/jas.v9n7p236

URL: https://doi.org/10.5539/jas.v9n7p236

The research is financed by King Abdulaziz City for Science and Technology, KSA.

\begin{abstract}
Moringa olifera leaf extract at different concentrations were used to evaluate their effects on three cereal forages (Sorghum bicolor L. Moench, Penisetum typhoideum Rich and Sorghum Sudanese) grown under stress environment of soil and water salinity in an arid environment. Three independent experiments carried out at King Abdulaziz University Experimental Station, Makkah province during 2015 and 2016. Treatments consisted of four concentrations of Moringa olifera leaf extract: $(\mathrm{C} 1=1 \mathrm{ml}$ of juice $+10 \mathrm{ml}$ of distilled water , $\mathrm{C} 2=1 \mathrm{ml}$ of juice $+20 \mathrm{ml}$ of distilled water, $\mathrm{C} 3=1 \mathrm{ml}$ of juice $+30 \mathrm{ml}$ of distilled water and $\mathrm{C} 4=1 \mathrm{ml}$ of juice $+40 \mathrm{ml}$ of distilled water in addition to distilled water alone as a control). Results showed that the higher concentration $\mathrm{C} 1$ contained the highest amount of inorganic elements and growth hormones compared to other concentrations. This in turn reflected in significant higher growth and forage yields of the three forage crops tested. Significant increases in growth and forage yields in both seasons reported for the higher concentration $\mathrm{C} 1$ compared to others. Fresh and dry forage yields of Millet, during 2016, increased by the higher concentration over the control treatment by 17.67 and $4.87 \%$, respectively. Results indicated the effectiveness of Moringa leaf extract in improving growth and increasing productivity of cereal forages under harsh environment of salinity and aridity.
\end{abstract}

Keywords: cereal forages, growth hormones, Moringa leaf extract, productivity, salinity

\section{1-Introduction}

The origin of Moringa olifera tree is the Hamalanian Mountains in the Indian Continent (Osman \& Abohassan, 2015). The geographic distribution of Moringa extends from Asia, India, Arabian Pensiula, and Africa to South and Central America. The tree is rich in its nutritive values for human and animals as well as containing many medicinal and chemical substances for other uses to be called the miracle tree (Osman \& Abuhassan, 2015). This feature coupled with its geographical distribution gives the tree a special importance as its growth cover places that are highly populated with high poverty rates (Osman \& Abohassan, 2015). Among the different usages of Moringa is the leaf extract as a growth hormone promotor for many crops (Price, 2007; Muhamman et al., 2013; Amirigbal et al., 2014).

The use of Moringa leaf extracts as a possible plant enhancer can provide a relatively environmentally friendly, easily accessible and affordable means of increasing crop yields to meet the growing demand for food all over the world, considering the global increasing population rate with its threatening hunger waves. Extracts from fresh Moringa leaves could be used to produce an effective plant growth promoter increasing yield by $25-30 \%$ for nearly any crop (Price, 2007). Amirigbal et al. (2014) reported that three sprays of Moringa and brassica leaf extracts significantly affected plant height, number of branches per plant, number of pods per plant, number of seeds per pod seed yield as well as biological yield of canola as compared to their sole application.

The leaf extract of Moringa reported to increase the yield of many crops (Alkinbode \& Ikotun, 2008; Foidle et al., 2001). This positive effect of Moringa leaf extract on growth and yields has also been reported for many field 
crops: Mvumi et al. (2012) and Emongor (2015) on onion and kidney beans, Muhamman et al. (2013) on tomato, Abdalla (2013) on rocket, and Mohammed et al. (2013) on onions.

The significance of Moringa leaf juice lies in the Zeatin. Zeatin is one of the phytohormones that are the major components of oil and protein structure (Mir et al., 2009). Zeatin is a part of the compound cytokinins, which stimulate cell division, growing cell tissue, delay the process of senescence and ageing in plant tissue and promote nutrient partitioning and uptake (Emongor, 2002; Andrews, 2006; Taiz \& Zieger, 2002).

Traditionally, there are five groups of growth regulators including auxins, gibberellins, abscisic acid, ethylene and cytokinins (Prosecus, 2006). Cytokinins enhance food production, and Zeatin is one of the most common forms of naturally occurring cytokinins in plants. Moringa leaves gathered from various parts of the world were found to have high Zeatin concentrations of between five and $200 \mu \mathrm{g} / \mathrm{g}$ of leaves (Alawady, 2003).

Cereal crops (grain and forages) are important sources of carbohydrates and fibers for humans and animals. Their production, area wise and quantities, exceeded any other agronomic crops. For people living in rural areas and in most developing countries enhancing crop production via high cost inorganic fertilizers are beyond their financial capabilities. Therefore, the objective of this study was to look into alternatives that are cost effective, available and environmentally friendly. All these features are strongly true in Moringa trees, and considering its wide spread natural growth in Africa, Asia, South America and many other parts of the world, which makes it a higher candidate for such research. Yasmeen et al. (2013) reported that Moringa leaf extract when it applied for drought or salt stressed plants modified plant phenotypic response to positively affect growth and productivity with alteration in metabolic processes. Moreover, environmental stresses of soil and water salinities under arid lands, where this research was conducted, was another objective as to evaluate Moringa leaf extracts on performance of the tested crops under such environment.

\section{Materials and Methods}

Moringa trees, from which leaves were collected for the extraction of juice, were seven years old growing in the same experimental farm in which the field experiments were conducted.

\subsection{Moringa Leaf Extract}

Moringa olifera leaf extract was prepared after collection of fresh green leaves using a conventional electric mixer, afterwards The mixture was passed through a cloth sieve to separate the juice from the residue, The juice was collected into 500 liter flask and four different concentrations were then prepared as follows:

1) $1 \mathrm{ml}$ from juice mixed with $10 \mathrm{ml}$ of distilled water (1:10 by volume) - (C1);

2) $1 \mathrm{ml}$ of juice mix with $20 \mathrm{ml}$ of distilled water $(1: 20)-(\mathrm{C} 2)$;

3) $1 \mathrm{ml}$ of juice mix with $30 \mathrm{ml}$ of distilled water (1:30) - (C3);

4) $1 \mathrm{ml}$ of juice mix with $40 \mathrm{ml}$ of distilled water (1:40) - (C4);

5) Distilled water only as a control - (C5).

These four concentrations in addition to the control sprayed on three cereal crops at a rate of $25 \mathrm{ml} / \mathrm{plant}$ at an interval of two weeks following emergence. The cereal crops were Sudan grass, forage sorghum, and millet, and each crop was planted as an independent field experiment.

A randomized complete block design with three replicates was used for each experiment; each replicate contained five randomly assigned treatments with plot size (experimental unit) of $1 \times 1 \mathrm{~m}$ for each treatment. The three forage crops were planted in continuous rows $80-\mathrm{cm}$ apart and watered via perforated plastic pipes along the row. Borehole was the source of irrigation water that contained 3000 TDS (ppm) and the soil was a saline one. Measurements of growth parameters were taken at forage harvest. Ten randomly selected plants from middle row were used for each growth parameter measured. For yield parameter, the entire plot $(1 \times 1 \mathrm{~m})$ was used to estimate forage fresh and dry yields.

The following growth and yield parameters taken during the course of the study, which lasted for two years: plant height, leaf area, number of leaves/plant, stem diameter, fresh and dry yields.

\subsection{Chemical Analysis of Hormonal and Inorganic Minerals}

\subsubsection{Hormonal Analysis}

Juice extract was prepared from green Moringa leaves and green twigs after crushed by a conventional kitchen mixer. The juice separated from residue using a cotton cloth as a filter. The same treatments described above were used for hormonal analysis: 
Afterwards each concentration (C1 to C5) mixed with cold redistilled 95\% ethanol, kept in a dark bottle, and deep-freeze overnight before assay started. The fraction of the ethanol extract was carried out according to the method described by Wasfy et al. (1974). The Acidic fraction contain the acidic hormones (IAA, GA, and ABA) while the aqueous fraction comprised the cytokinins. The growth promoters (auxins, gibberellins and cytokinins) and the growth inhibitors ABA quantified using high performance liquid chromatography (HPLC) according to the method of Muller and Hilgenberg (1986).

\subsubsection{Inorganic Minerals}

Mineral elements extracted from leaf tissues according to Chapman and Pratt (1961), Phosphorus determined according to the method described by Humphries (1956) while Potassium determined photometrically according to Williams and Twine (1961), Calcium and Magnesium determined by atomic absorption spectrophotometer according to AOAC (1984) and total nitrogen was determined by Micro-kejeldhal, Tector model 1026 after digestion in sulphuric acid (Horwiz, 2002).

\subsection{Soil and Water Analysis of the Experimental Site}

Soil chemical analysis of the experimental site, in top $30 \mathrm{~cm}$ depth, showed a soil $\mathrm{pH}$ of 8.25 , an Ec of $1.61 \mathrm{ds}^{-1}$, $\mathrm{OM}$ of $0.1 \%$ and $\mathrm{N}, \mathrm{P}, \mathrm{K}, \mathrm{Ca}, \mathrm{Mg}$, and $\mathrm{Na}$ of $0.32,0.129,2.5,3.6,6.3$ and $16.8 \mathrm{mg} \mathrm{kg}^{-1}$, respectively. Irrigation water (which was a borehole water), analysis contained 3000 TDS (ppm) with Nacl the dominant salt.

\section{Results}

Inorganic contents of leaf extract are presented in Table 1. The concentration of all inorganic contents dropped with dilution of the juice. The control treatment (C5) contained negligible amounts of the inorganic compounds, as it was distilled water.

Table 1. Inorganic contents of Moringa ( $\mathrm{mg} / \mathrm{kg}$ dry weight)

\begin{tabular}{llllll}
\hline Treatment & $\mathrm{N}$ & $\mathrm{P}$ & $\mathrm{K}$ & $\mathrm{Ca}$ & $\mathrm{Mg}$ \\
\hline $\mathrm{C} 1$ & 37.5 & 8.2 & 16.5 & 48.5 & 5.7 \\
$\mathrm{C} 2$ & 32.4 & 7.3 & 12.7 & 38.6 & 4.2 \\
$\mathrm{C} 3$ & 27.5 & 5.4 & 10.3 & 32.4 & 3.6 \\
$\mathrm{C} 4$ & 19.3 & 2.3 & 8.7 & 21.2 & 2.5 \\
$\mathrm{C} 5$ & 0.0008 & 0.0001 & 0.0001 & 0.0001 & 0.0002 \\
\hline
\end{tabular}

Note. $\mathrm{C} 1=1 \mathrm{ml}$ of Moringa juice with $10 \mathrm{ml}$ of distilled water; $\mathrm{C} 2=1 \mathrm{ml}$ of Moringa juice with $20 \mathrm{ml}$ of distilled water; $\mathrm{C} 3=1 \mathrm{ml}$ of Moringa juice with $30 \mathrm{ml}$ of distilled water; $\mathrm{C} 4=1 \mathrm{ml}$ of Moringa juice with $40 \mathrm{ml}$ of distilled water; $\mathrm{C} 5=$ only distilled water.

Similar to inorganic contents, the hormonal concentration dropped with increase in dilution rate, while no hormones in the control treatment (distilled water) as shown in Table 2.

Table 2. Hormonal contents of Moringa extract ( $\mathrm{mg} / \mathrm{kg}$ fresh weight)

\begin{tabular}{lllll}
\hline Treatment & Cytokinins & Auxins & Gibberellins & ABA \\
\hline C1 & 27.5 & 15.9 & 16.8 & 10.5 \\
C2 & 23.7 & 13.0 & 14.5 & 8.2 \\
C3 & 19.6 & 9.6 & 12.2 & 7.6 \\
C4 & 15.3 & 5.3 & 6.7 & 5.4 \\
C5 & - & - & - & - \\
\hline
\end{tabular}

Note. $\overline{\mathrm{C} 1}=1 \mathrm{ml}$ of Moringa juice with $10 \mathrm{ml}$ of distilled water; $\mathrm{C} 2=1 \mathrm{ml}$ of Moringa juice with $20 \mathrm{ml}$ of distilled water; $\mathrm{C} 3=1 \mathrm{ml}$ of Moringa juice with $30 \mathrm{ml}$ of distilled water; $\mathrm{C} 4=1 \mathrm{ml}$ of Moringa juice with $40 \mathrm{ml}$ of distilled water; $\mathrm{C} 5=$ only distilled water.

\subsection{Effect of Treatments on Growth and Yield of Sudan Grass}

Results of different concentrations of Moringa leaf extract on Sudan grass are presented in Table 3 for both seasons 2015 (April) and 2016 (February and April). All growth parameters of Sudan grass were significantly (P 
$<0.05$ ) affected by the different concentrations of the Moringa Juice extract in both seasons, with exception of plant height in 2015 and stem thickness in 2016. Taller, thicker and leafy Sudan grass plants were recorded for the higher concentration $\mathrm{C} 1$ compared to other concentrations.

Table3. Effect of different concentrations of Moringa leaf extract on growth parameters of Sudan grass

\begin{tabular}{|c|c|c|c|c|c|c|c|c|c|}
\hline \multirow{2}{*}{ Teat. Conc. } & \multicolumn{3}{|c|}{ Plant height $(\mathrm{cm})$} & \multicolumn{3}{|c|}{ Stem thickness $(\mathrm{mm})$} & \multicolumn{3}{|c|}{ Leaf number } \\
\hline & Apr., 2015 & Feb., 2016 & Apr., 2016 & Apr., 2015 & Feb., 2016 & Apr., 2016 & Apr., 2015 & Feb., 2016 & Apr., 2016 \\
\hline $\mathrm{C} 1$ & $121.83 \mathrm{a}$ & $181.6 \mathrm{a}$ & $135.0 \mathrm{a}$ & $6.23 a$ & $0.49 \mathrm{a}$ & $0.41 \mathrm{a}$ & $5.80 \mathrm{a}$ & $6.5 \mathrm{a}$ & $5.9 \mathrm{a}$ \\
\hline $\mathrm{C} 2$ & $107.90 \mathrm{a}$ & $174.86 \mathrm{~b}$ & $122.6 \mathrm{~b}$ & $5.50 \mathrm{ab}$ & $0.35 \mathrm{ab}$ & $0.40 \mathrm{a}$ & $5.4 \mathrm{ab}$ & $6.3 \mathrm{ab}$ & $5.45 \mathrm{~b}$ \\
\hline $\mathrm{C} 3$ & $116.50 \mathrm{a}$ & $173.30 \mathrm{bc}$ & $118.6 \mathrm{c}$ & $4.33 b$ & $0.27 b$ & $0.40 \mathrm{a}$ & $4.5 \mathrm{~b}$ & $6.2 \mathrm{ab}$ & $5.45 \mathrm{~b}$ \\
\hline $\mathrm{C} 4$ & $119.67 \mathrm{a}$ & $172.49 \mathrm{c}$ & $118.5 \mathrm{c}$ & $4.63 \mathrm{ab}$ & $0.30 \mathrm{~b}$ & $0.39 \mathrm{a}$ & $5.3 \mathrm{ab}$ & $6.0 \mathrm{ab}$ & $4.35 \mathrm{~b}$ \\
\hline $\mathrm{C} 5$ & $115.40 \mathrm{a}$ & $140.1 \mathrm{~d}$ & $117.9 \mathrm{c}$ & $5.53 \mathrm{ab}$ & $0.27 b$ & $0.37 \mathrm{a}$ & $4.8 \mathrm{ab}$ & $5.1 \mathrm{~b}$ & $4.00 \mathrm{c}$ \\
\hline LSD & 31.64 & 1.67 & 3.85 & 1.68 & 0.17 & 0.11 & 1.2 & 1.19 & 0.35 \\
\hline $\mathrm{CV}$ & 14.45 & 0.57 & 1.67 & 17.07 & 27.65 & 15.81 & 12.43 & 10.58 & 25.03 \\
\hline
\end{tabular}

Note. $\mathrm{C} 1=1 \mathrm{ml}$ of Moringa juice with $10 \mathrm{ml}$ of distilled water; $\mathrm{C} 2=1 \mathrm{ml}$ of Moringa juice with $20 \mathrm{ml}$ of distilled water; $\mathrm{C} 3=1 \mathrm{ml}$ of Moringa juice with $30 \mathrm{ml}$ of distilled water; $\mathrm{C} 4=1 \mathrm{ml}$ of Moringa juice with $40 \mathrm{ml}$ of distilled water; $\mathrm{C} 5=$ only distilled water); Values with same letters are not significantly different from each other; $\mathrm{LSD}=$ least significant difference; $\mathrm{CV}=$ coefficient of variation .

The effect of different concentrations of Moringa juice on fresh and dry yields of Sudan grass is presented in Table 4. Significant differences in fresh and dry yields of Sudan grass were reported for the different concentrations in comparison to the control (C5) in both seasons. The higher concentration $\mathrm{C} 1$ always recorded higher fresh and dry yields in both seasons, whereas the control C5 resulted in the lowest fresh and dry yield.

Table 4. Effect of different concentrations of Moringa leaf extract on fresh and dry yields Sudan grass

\begin{tabular}{|c|c|c|c|c|c|c|}
\hline \multirow{2}{*}{ Treat. Conc. } & \multicolumn{3}{|c|}{ Fresh Weight (ton ha ${ }^{-1}$ ) } & \multicolumn{3}{|c|}{ Dry Weight (ton $\mathrm{ha}^{-1}$ ) } \\
\hline & April, 2015 & Feb., 2016 & April, 2016 & April, 2015 & Feb., 2016 & April, 2016 \\
\hline $\mathrm{C} 1$ & $15.60 \mathrm{a}$ & $26.62 \mathrm{a}$ & $15.96 \mathrm{a}$ & $8.80 \mathrm{a}$ & $17.94 a$ & $4.51 \mathrm{a}$ \\
\hline $\mathrm{C} 2$ & $12.80 \mathrm{~b}$ & $21.84 b$ & $12.77 \mathrm{ab}$ & $7.20 \mathrm{a}$ & $14.71 \mathrm{~b}$ & $4.00 \mathrm{ab}$ \\
\hline $\mathrm{C} 3$ & $12.59 \mathrm{~b}$ & $16.82 \mathrm{c}$ & $11.49 \mathrm{~b}$ & $3.90 \mathrm{~b}$ & $11.29 \mathrm{c}$ & $3.50 \mathrm{bc}$ \\
\hline $\mathrm{C} 4$ & $11.50 \mathrm{~b}$ & $13.08 \mathrm{~d}$ & $12.15 b$ & $3.70 \mathrm{~b}$ & $9.49 \mathrm{~d}$ & $3.54 \mathrm{bc}$ \\
\hline $\mathrm{C} 5$ & $11.40 \mathrm{~b}$ & $12.90 \mathrm{~d}$ & $11.30 \mathrm{~b}$ & $2.60 \mathrm{~b}$ & $8.38 \mathrm{~d}$ & $3.37 \mathrm{c}$ \\
\hline LSD & 2.30 & 1.01 & 3.39 & 2.90 & 1.38 & 0.55 \\
\hline $\mathrm{CV}$ & 14.3 & 2.96 & 14.20 & 29.95 & 5.93 & 7.75 \\
\hline
\end{tabular}

Note. $\mathrm{C} 1=1 \mathrm{ml}$ of Moringa juice with $10 \mathrm{ml}$ of distilled water; $\mathrm{C} 2=1 \mathrm{ml}$ of Moringa juice with $20 \mathrm{ml}$ of distilled water; $\mathrm{C} 3=1 \mathrm{ml}$ of Moringa juice with $30 \mathrm{ml}$ of distilled water; $\mathrm{C} 4=1 \mathrm{ml}$ of Moringa juice with $40 \mathrm{ml}$ of distilled water; $\mathrm{C} 5=$ only distilled water); Values with same letters are not significantly different from each other; LSD = least significant difference; $\mathrm{CV}=$ coefficient of variation.

\subsection{Effect of Treatments on Growth and Yield of Forage Sorghum}

Results of the effect of Moringa Juice extract on growth parameters of forage sorghum are presented in Table 5. Moringa leaf juice extract had a significant effect on growth parameters of forage Sorghum in both seasons except pant height and stem thickness in 2015 and number of leaves per plant in 2016. Taller, thicker and leafy Sorghum forage plants were recorded for the higher concentration $\mathrm{Cl}$ compare to other concentrations and the control, which recorded the lowest height, thickness and number of leaves. 
Table 5. Effect of different concentrations of Moringa leaf extract on Moringa leaf extracts growth parameters of forage Sorghum

\begin{tabular}{|c|c|c|c|c|c|c|c|c|c|c|}
\hline \multirow[b]{2}{*}{ Treat. Conc. } & \multicolumn{2}{|c|}{ Plant height $(\mathrm{cm})$} & \multicolumn{2}{|c|}{ Stem thickness (mm) } & \multicolumn{2}{|c|}{ Leaf number } & \multicolumn{2}{|c|}{ Leaf area $\left(\mathrm{cm}^{2}\right)$} & \multicolumn{2}{|c|}{ Leaf stem ratio } \\
\hline & $\begin{array}{l}\text { Apr., } \\
2015\end{array}$ & $\begin{array}{l}\text { Mar., } \\
2016\end{array}$ & $\begin{array}{l}\text { Apr., } \\
2015\end{array}$ & $\begin{array}{l}\text { Mar., } \\
2016\end{array}$ & $\begin{array}{l}\text { Apr., } \\
2015\end{array}$ & $\begin{array}{l}\text { Mar., } \\
2016\end{array}$ & $\begin{array}{l}\text { Apr., } \\
2016\end{array}$ & $\begin{array}{l}\text { Mar., } \\
2016\end{array}$ & $\begin{array}{l}\text { Apr., } \\
2015\end{array}$ & $\begin{array}{l}\text { Mar., } \\
2016\end{array}$ \\
\hline $\mathrm{C} 1$ & $125.27 \mathrm{a}$ & $98.53 \mathrm{a}$ & $6.12 \mathrm{a}$ & $0.80 \mathrm{a}$ & $6.86 \mathrm{a}$ & $5.66 \mathrm{a}$ & $5.94 a$ & $6.30 \mathrm{a}$ & $1.94 \mathrm{a}$ & $1.85 \mathrm{a}$ \\
\hline $\mathrm{C} 2$ & $122.76 a$ & $93.76 b$ & $6.07 \mathrm{a}$ & $0.76 \mathrm{a}$ & $6.76 \mathrm{a}$ & $5.66 \mathrm{a}$ & $5.83 \mathrm{a}$ & $6.18 b$ & $1.94 \mathrm{a}$ & $1.83 \mathrm{a}$ \\
\hline C3 & $120.93 a$ & $92.91 b$ & $6.00 \mathrm{a}$ & $0.76 \mathrm{a}$ & $6.55 \mathrm{a}$ & $5.53 \mathrm{a}$ & $5.72 \mathrm{a}$ & $5.83 \mathrm{c}$ & $1.58 \mathrm{~b}$ & $1.65 b$ \\
\hline $\mathrm{C} 4$ & $118.15 \mathrm{a}$ & $90.16 b c$ & $5.24 \mathrm{a}$ & $0.74 \mathrm{a}$ & $6.11 b c$ & $5.60 \mathrm{a}$ & $5.83 \mathrm{a}$ & $5.80 \mathrm{c}$ & $1.36 \mathrm{c}$ & $1.60 \mathrm{~b}$ \\
\hline C5 & $114.50 \mathrm{ab}$ & $87.33 \mathrm{c}$ & $5.23 \mathrm{a}$ & $0.73 \mathrm{a}$ & $5.96 \mathrm{c}$ & $5.20 \mathrm{a}$ & $5.52 \mathrm{a}$ & $4.70 \mathrm{~d}$ & $1.34 \mathrm{~d}$ & $1.24 \mathrm{c}$ \\
\hline LSD & 7.05 & 4.54 & 2.24 & 0.20 & 0.49 & 1.17 & 0.90 & 0.20 & 0.11 & 0.15 \\
\hline $\mathrm{CV}$ & 15.99 & 2.6 & 20.77 & 14.38 & 4.08 & 11.27 & 8.29 & 8.50 & 15.20 & 13.70 \\
\hline
\end{tabular}

Note. $\mathrm{C} 1=1 \mathrm{ml}$ of Moringa juice with $10 \mathrm{ml}$ of distilled water; $\mathrm{C} 2=1 \mathrm{ml}$ of Moringa juice with $20 \mathrm{ml}$ of distilled water; $\mathrm{C} 3=1 \mathrm{ml}$ of Moringa juice with $30 \mathrm{ml}$ of distilled water; $\mathrm{C} 4=1 \mathrm{ml}$ of Moringa juice with $40 \mathrm{ml}$ of distilled water; $\mathrm{C} 5=$ only distilled water); Values with same letters are not significantly different from each other; $\mathrm{LSD}=$ least significant difference; $\mathrm{CV}=$ coefficient of variation

Effect of treatments on fresh and dry yields of forage Sorghum are presented in Table 6. Significant $(\mathrm{P}<0.05)$ differences on fresh and dry yields, because of Moringa leaf extract, were recorded during both seasons. Similar to Sudan grass results, higher fresh and dry yields were recorded for the higher concentration $\mathrm{C} 1$ and the lowest yield was recorded for the control. It is worth mentioning here that higher yields recorded during second season of 2016 compared to 2015 regardless of treatments used. This might be due to weather variations (especially rain and temperature) during both seasons.

Table 6. Effect of different concentrations of Moringa leaf extract on fresh and dry yields of forage Sorghum

\begin{tabular}{llllll}
\hline \multirow{2}{*}{ Treat. Conc. } & \multicolumn{2}{c}{ Fresh weight $\left(\right.$ ton $\left.\mathrm{ha}^{-1}\right)$} & & \multicolumn{2}{c}{ Dry weight (ton/ha) } \\
\cline { 2 - 3 } \cline { 5 - 6 } & April2015 & March2016 & & April2015 & March2016 \\
\hline C1 & $1.08 \mathrm{a}$ & $12.49 \mathrm{a}$ & & $0.27 \mathrm{a}$ & $3.12 \mathrm{a}$ \\
$\mathrm{C} 2$ & $1.05 \mathrm{a}$ & $12.13 \mathrm{a}$ & & $0.26 \mathrm{ab}$ & $3.03 \mathrm{a}$ \\
$\mathrm{C} 3$ & $0.99 \mathrm{a}$ & $8.98 \mathrm{~b}$ & & $0.24 \mathrm{bc}$ & $2.24 \mathrm{~b}$ \\
$\mathrm{C} 4$ & $0.86 \mathrm{~b}$ & $8.41 \mathrm{~b}$ & & $0.22 \mathrm{~cd}$ & $2.10 \mathrm{~b}$ \\
$\mathrm{C} 5$ & $0.83 \mathrm{~b}$ & $8.40 \mathrm{~b}$ & & $0.20 \mathrm{~d}$ & $2.10 \mathrm{~b}$ \\
LSD & 0.10 & 1.80 & & 0.02 & 0.003 \\
CV & 28.5 & 9.46 & & 4.54 & 8.07 \\
\hline
\end{tabular}

Note. $\mathrm{C} 1=1 \mathrm{ml}$ of Moringa juice with $10 \mathrm{ml}$ of distilled water; $\mathrm{C} 2=1 \mathrm{ml}$ of Moringa juice with $20 \mathrm{ml}$ of distilled water; $\mathrm{C} 3=1 \mathrm{ml}$ of Moringa juice with $30 \mathrm{ml}$ of distilled water; $\mathrm{C} 4=1 \mathrm{ml}$ of Moringa juice with $40 \mathrm{ml}$ of distilled water; $\mathrm{C} 5=$ only distilled water); Values with same letters are not significantly different from each other; $\mathrm{LSD}=$ least significant difference; $\mathrm{CV}=$ coefficient of variation .

\subsection{Effect of Treatments on Growth and Yield of Millet}

Results of the effect of treatments on growth and yield parameters of millet are presented in Tables 7 and 8 , respectively. Significant differences for growth parameters of plant height stem diameter and number of leaves per plant were reported in both seasons except April of 2016 for number of leaves per plant (Table 7). The tallest, thickest and leafy plants recorded for the higher concentration $\mathrm{C} 1$ except for plant height in April 2015 and March 2016, when taller plants recorded for the Control C5 and the concentration C2, respectively. 
Table 7. Effect of different concentrations of Moringa leaf extract on growth parameters of millet

\begin{tabular}{|c|c|c|c|c|c|c|c|c|c|c|}
\hline \multirow[b]{2}{*}{ Treat. Conc. } & \multicolumn{2}{|c|}{ Plant height $(\mathrm{cm})$} & \multicolumn{2}{|c|}{ Stem thickness $(\mathrm{mm})$} & \multicolumn{2}{|c|}{ Leaf number } & \multicolumn{2}{|c|}{ Leaf area $\left(\mathrm{cm}^{2}\right)$} & \multicolumn{2}{|c|}{ Leaf stem ratio } \\
\hline & $\begin{array}{l}\text { Apr., } \\
2015\end{array}$ & $\begin{array}{l}\text { Mar., } \\
2016\end{array}$ & $\begin{array}{l}\text { Apr., } \\
2015\end{array}$ & $\begin{array}{l}\text { Mar., } \\
2016\end{array}$ & $\begin{array}{l}\text { Apr., } \\
2015\end{array}$ & $\begin{array}{l}\text { Mar., } \\
2016\end{array}$ & $\begin{array}{l}\text { Apr., } \\
2016\end{array}$ & $\begin{array}{l}\text { Mar., } \\
2016\end{array}$ & $\begin{array}{l}\text { Apr., } \\
2015\end{array}$ & $\begin{array}{l}\text { Mar., } \\
2016\end{array}$ \\
\hline $\mathrm{C} 1$ & $103.33 \mathrm{c}$ & $100.66 \mathrm{~b}$ & $4.76 \mathrm{a}$ & $0.42 \mathrm{a}$ & $6.26 a$ & $5.10 \mathrm{a}$ & $5.94 a$ & $5.85 \mathrm{a}$ & $1.46 \mathrm{a}$ & $1.42 \mathrm{a}$ \\
\hline $\mathrm{C} 2$ & $116.66 \mathrm{bc}$ & $107.10 \mathrm{a}$ & $5.56 \mathrm{ab}$ & $0.37 b$ & $6.53 \mathrm{a}$ & $4.80 \mathrm{ab}$ & $5.93 \mathrm{a}$ & $5.67 \mathrm{a}$ & $1.40 \mathrm{a}$ & $1.39 \mathrm{a}$ \\
\hline $\mathrm{C} 3$ & $123.33 b$ & $100.23 b c$ & $5.26 \mathrm{~b}$ & $0.36 \mathrm{~b}$ & $6.56 \mathrm{a}$ & $4.80 \mathrm{ab}$ & $5.85 \mathrm{a}$ & $5.52 \mathrm{a}$ & $1.32 \mathrm{~b}$ & $1.18 \mathrm{~b}$ \\
\hline $\mathrm{C} 4$ & $105.66 \mathrm{c}$ & $104.60 \mathrm{a}$ & $6.23 \mathrm{a}$ & $0.33 \mathrm{c}$ & $5.96 \mathrm{~b}$ & $4.80 \mathrm{ab}$ & $5.83 \mathrm{a}$ & $4.70 \mathrm{~b}$ & $1.23 \mathrm{~b}$ & $1.14 \mathrm{~b}$ \\
\hline $\mathrm{C} 5$ & $152.00 \mathrm{a}$ & $97.36 \mathrm{c}$ & $5.16 \mathrm{~b}$ & $0.32 \mathrm{c}$ & $5.90 \mathrm{~b}$ & $4.50 \mathrm{~b}$ & $5.77 \mathrm{a}$ & $4.30 \mathrm{~b}$ & $1.22 \mathrm{c}$ & $1.00 \mathrm{c}$ \\
\hline LSD & 16.25 & 2.97 & 0.86 & 0.02 & 0.27 & 0.54 & 0.66 & 0.80 & 0.07 & 0.13 \\
\hline $\mathrm{CV}$ & 7.18 & 1.54 & 8.48 & 4.03 & 9.47 & 5.97 & 5.98 & 6.99 & 20.97 & 16.96 \\
\hline
\end{tabular}

Note. $\mathrm{C} 1=1 \mathrm{ml}$ of Moringa juice with $10 \mathrm{ml}$ of distilled water; $\mathrm{C} 2=1 \mathrm{ml}$ of Moringa juice with $20 \mathrm{ml}$ of distilled water; $\mathrm{C} 3=1 \mathrm{ml}$ of Moringa juice with $30 \mathrm{ml}$ of distilled water; $\mathrm{C} 4=1 \mathrm{ml}$ of Moringa juice with $40 \mathrm{ml}$ of distilled water; $\mathrm{C} 5$ = only distilled water); Values with same letters are not significantly different from each other; LSD = least significant difference; $\mathrm{CV}=$ coefficient of variation.

Effects of treatments on fresh and dry yields of millet are presented in Table 8. Fresh and dry yields of millet were not significantly affected by treatments in April 2015. However, significant differences were recorded for both fresh and dry yields during 2016. Again, variations in weather conditions could be an explanation for this. Fresh and dry yields, during 2016, increased by the higher concentration over the control treatment by 17.67 and $4.87 \%$, respectively.

Table 8. Effect of different concentrations of Moringa leaf extract on forage fresh and dry yields of millet

\begin{tabular}{llllll}
\hline \multirow{2}{*}{ Treat. Conc. } & \multicolumn{2}{c}{ Fresh weight $\left(\right.$ ton ha $\left.^{-1}\right)$} & & \multicolumn{2}{c}{ Dry weight $\left(\right.$ ton ha $\left.{ }^{-1}\right)$} \\
\cline { 2 - 3 } \cline { 5 - 6 } & April 2015 & March 2016 & & April 2015 & March 2016 \\
\hline C1 2 & $4.54 \mathrm{a}$ & $18.67 \mathrm{a}$ & & $0.13 \mathrm{a}$ & $5.87 \mathrm{a}$ \\
$\mathrm{C} 3$ & $4.30 \mathrm{a}$ & $15.40 \mathrm{~b}$ & & $0.12 \mathrm{a}$ & $4.53 \mathrm{~b}$ \\
$\mathrm{C} 4$ & $3.75 \mathrm{a}$ & $13.96 \mathrm{~b}$ & & $0.11 \mathrm{a}$ & $4.50 \mathrm{~b}$ \\
$\mathrm{C} 5$ & $3.60 \mathrm{a}$ & $13.31 \mathrm{~b}$ & & $0.11 \mathrm{a}$ & $4.17 \mathrm{~b}$ \\
LSD & $3.42 \mathrm{a}$ & $11.54 \mathrm{~b}$ & & $0.10 \mathrm{a}$ & $3.88 \mathrm{~b}$ \\
CV & 2.69 & 3.25 & & 2.69 & 1.30 \\
\hline
\end{tabular}

Note. $\mathrm{C} 1=1 \mathrm{ml}$ of Moringa juice with $10 \mathrm{ml}$ of distilled water; $\mathrm{C} 2=1 \mathrm{ml}$ of Moringa juice with $20 \mathrm{ml}$ of distilled water; $\mathrm{C} 3=1 \mathrm{ml}$ of Moringa juice with $30 \mathrm{ml}$ of distilled water; $\mathrm{C} 4=1 \mathrm{ml}$ of Moringa juice with $40 \mathrm{ml}$ of distilled water; C5 = only distilled water); Values with same letters are not significantly different from each other; $\mathrm{LSD}=$ least significant difference; $\mathrm{CV}=$ coefficient of variation.

\section{Discussion}

\subsection{Effect of Moringa Leaf Extract on Growth Parameters}

Chemical and hormonal analysis of Moringa leaf extract clearly showed that the higher concentration treatment (C1) revealed the highest inorganic contents compared to other concentrations. Furthermore, the higher concentration (C1) showed the higher concentration of the hormones, especially cytokinins, compared to other concentrations. Consequently, it expected to affect growth attributes of plant height. Stem diameter and number of leaves in a positive way. Moringa leaf juice is rich with growth hormones, especially Zeatin, that has been reported to increase the crop yield in the range of 10 to 45\% (Muhammad, 2014). Moringa leaf juice also contains micronutrients in sufficient amounts and suitable proportions that increase the growth and yield of a variety of crops ranging from cereals to oil crops, from fiber to sugar crops and from forages to tuber crops (Price, 2007; Muhamman et al., 2013; Amirigbal et al., 2014). Rehman et al. (2017) reported that Moringa leaf extract when applied to wheat plants increased plant height, number of tillers, increased grain yield and delayed leaf senescence. They related that to Moringa leaf extract being rich in Zeatin, a cytokinins maintained the green photosynthetic area, therefore contributed to higher grain yield. It should be recalled that the three cereals 
forages were grown under stress environment of water and soil salinities. Yasmeen et al. (2013) reported that Moringa leaf extract when applied on for drought or salt stressed plants modified plant phenotypic response positively affect growth and productivity with alteration in metabolic processes

\subsection{Effect of Moringa Leaf Extract on Yield}

Forage yield largely determined by growth attributes of plant height, stem diameter, size, and number of leaves carried by the plant, that resemble the resultant of yield. As shown from the results, forage yield increased significantly by the higher concentration $(\mathrm{C} 1)$ of Moringa Juice extracts in both seasons compared to other concentrations. Several researchers found similar results with different crops: Mvumi et al. (2012) and Emongor (2015) on onion and kidney beans, Muhamman et al. (2013) on tomato, Abdalla (2013) on rocket, and Mohammed et al. (2013) on onions. As cytokinins are considered to be regulators of leaf senescence (Davis, 2007), therefore we hypothesized that with rich in Zeatin type of cytokinins and other regulators (Rady \& Mohamed, 2015), Moringa leaf extract can play a role to maintain photosynthetic area by delaying senescence and affecting source-sink strength to increase yield.

\section{Conclusion}

It can be concluded from the results of this study that Marina leaf extract without or with little dilution can increase growth and productivity of cereal forages grown in stressed environment. The spread of this tree in the Southern Hemisphere characterized by human explosions, poverty and aridity gives the tree special importance to be called the miracle tree. We recommend that under aridity, where salt stress prevails, use of Moringa leaf extract be used to replace inorganic expensive and environmentally polluting fertilizers.

\section{References}

Abdalla, M. (2013). The potential of Moringa olifera extract as biostimulant in enhancing the growth, biochemical and hormonal contents in rocket (Eruca sativa ssp. Sativa) plants. International Plant Physio. Biochem., 5(3), 42-49. https://doi.org/10.5897/IJPPB2012.026

Alawady, A. (2003). Moringa Tree: Nature's Pharmacy. Retrieved October 20, 2007, from $\mathrm{http}: / / \mathrm{www}$.islamonline.net/english/Science/2003/02article06.shtml

Alkinbode, O., \& Ikotun, T. (2008). Efficacy of certain plant extracts against seed-borne infection of Collectotrichume destructivum on cowpea. Afri. J. Biotech., 7(20), 3638-368.

Amirigbal, M., Nadeemakbar, A., Abbas, R., Khan, H., \& Maqsood, Q. (2014). Response of Canola to foliar application of Moring (Moringa olifera L.) and Brassica (Brassica napus L.) water extracts. International J. Agric. and Crop Sci., 14(7), 1431-1433. Retrieved from http://www.ijacs.com.IJACS/2014/7-14/1431-1433

Andrews, D. (2006). Nutraceutical Moringa composition. Retrieved from http://www.gooogle.com/patents/ US20060222882

AOAC. (1984). Official Method of Analysis of the Association of Official Analytical Chemists (14th ed.). Association of official Analytical Chemists, Washington, DC.

Chapman, H. D., \& Pratt, P. F. (1961). Methods of Analysis of Soils, Plants and Water. Soil Sci., 66, 412-421.

Davis, P. (2007). Plant hormones and their role in in plant growth and development (p. 732). Springer, Netherlands.

Emongor, V. E. (2002). Effect of benzyldenine and gibberellins on growth and yield components of common bean. UNISWA Res. J. Agr. Sci. Tech., 6(1), 65-72.

Emongor, V. E. (2015). Effect of Moringa (Moringa olifera) leaf extract on growth, yield components Snap Beans (Phaseolus vulgaris). British J. Appl. Sci. Tech., 6(2), 114-122. https://doi.org/10.9734/BJAST/ 2015/14795

Foidle, N., Makkar, H., \& Becker, H. (2001). The potential of Moringa olifera for agriculture and industrial uses. The multipurpose attributes of Moringa CTA publications. Wageningen, the Netherlands.

Horwiz, W. (2002). Official methods of AOAC (pp. 2077-2417). International Gaitherburg, Maryland, USA.

Humphries, E. C. (1956). Mineral components and ash analysis. Modern methods of plant analysis (Vol. 1, p. 148). Springer-Verlag, Berlin.

Mir, M. R., Lone, N. A., \& Khan, N. A. (2009). Impact of exogenously applied ethephon on physiological and yield attributes to two mustard cultivars under rain fed conditions. Appl. Biol. Res., 1(1), 44-46. 
Muhammad, A. I. (2014). Role of Moringa, Brassica and Sorghum water extracts in increasing crop growth and yield. American-Eurasians J. Agric and Environ. Sci., 14(11), 1150-1168. https://doi.org/10.5829/ idosi.aeajaes.2014.14.11.12436

Muhamman, M. A., Auwalu, B. M., Manga, A. A., \& Gibrin, J. M. (2013). Effects of aqueous extract of Moringa (Moringa olifera Lam.) and nitrogen rates on some physiological attributes and yield of Tomato. Int. J. Chem. Biol. Sci., 1(1), 67-74.

Muhammed, A., Muhammed, H., Muhammed, W., Muhammed, R., \& Muhammed, I. (2013). Allelopathy of Moring: A review. Sci. Agri., 3(1), 9-12.

Muhammed, R., Olurokooba, M., Akinyaju, J., \& Kambai, E. (2013). Evaluation of different concentrations and frequency of foliar application of Moringa extract on growth and yield of onions. Agrores., 13(3), 196-205. https://doi.org/10.4314/agrosh.v13i3.3S

Muller, P., \& Hilgenberg, W. (1986). Isomers of Zeatin and Zeatin ribosome in club root tissue: Evidence of trans-zeatin biosynthesis by plasma diophora brassicae. Physiol. Plant, 66, 245-250. https://doi.org/10.1111/ j.1399-3054.1986.tb02415.x

Mvumi, C., Tagwira, F., \& Albert, Z. C. (2012). Effect of Moringa extract on growth and yield of Tomato. Greener J. Agric. Sci., 2(5), 207-2011. https://doi.org/10.15580/GJAS.2013.1.111512264

Osman, H., \& Abohassan. (2015). Moringa: The strategic tree for the third Century (1st ed., p. 287). King Abdulaziz University Publishing Center.

Price, M. (2007). The Moringa Tree. ECHO Tech. Note, eBook. Retrieved from http://miracletrees.org/ moringa-doc/ebookMoringa.pdf

Prosecus, P. (2006). Biosynthesis plant hormones and growth regulators. Chemistry and Biology. Biosynth. Agr. Co., Swizerland.

Rady, M. M., \& Mohamed, G. F. (2015). Modulation of salt stress effects on the growth, physiochemical attributes and yields of Phaseolus vulgaris L. plants by the combined application of salicylic Q acid and Moringa leaf extract. Sci. Hort., 193, 105-113. https://doi.org/10.1016/j.scienta.2015.07.003

Rehman, H., Basra, S. M., Rady, M. M., Ghoneim, A. M., \& Wang. (2017). Moringa olifera leaf extract improves wheat growth and productivity by delaying senescence and source - Sink relationship. Int. J. Agric. Biol.

Taiz, H., \& Zieger, E. (2002). Plant Physiology (3rd ed., pp. 423-558). Sinauer Associates, Inc.

Wasfy, W., Shindy, E., \& Orrin, E. S. (1974). Identification of plant hormones from cotton ovules. Plant Physio., 55, 550-560. https://doi.org/10.1104/pp.55.3.550

Williams, S., \& Twine, M. (1961). Flame photometric method for Sodium, potassium and calcium. In K. Peach \& M. V. Tracey (Eds.), Modern Methods of plant analysis (Vol. 5, pp. 3-5). Springer-Verlag, Berlin.

Yasmeen, A., Basra, S. M., Wahid, A., Nouman, W., \& Husain, N. (2013). Improving drought resistance in wheat (Triticum aestivum) by exogenous application of growth enhancers. Int. J. Agric. Biol., 15(6), 1307-1312.

\section{Copyrights}

Copyright for this article is retained by the author(s), with first publication rights granted to the journal.

This is an open-access article distributed under the terms and conditions of the Creative Commons Attribution license (http://creativecommons.org/licenses/by/4.0/). 